Sari Pediatri, Vol. 8, No. 1, Juni 2006: $60-68$

\title{
Tata laksana Sindrom Nefrotik Kelainan Minimal pada Anak
}

\author{
Husein Albar
}

\begin{abstract}
Sindrom nefrotik kelainan minimal (SNKM) berdampak pada kesehatan fisik anak serta mental anak dan orang tua karena penyakit ini sering relaps, pengobatan lama, dan toksisitas obat yang serius. Pengobatan yang tidak adekuat potensial membahayakan hidup anak karena infeksi sekunder dan dapat menyebabkan tromboemboli, kelainan lipid, dan malnutrisi. Tata laksana SNKM meliputi tata laksana suportif, tata laksana komplikasi, dan tata laksana spesifik dengan obat imunosupresif untuk induksi dan mempertahankan remisi tanpa toksisitas obat yang serius. Sampai saat ini, kortikosteroid masih merupakan pilihan pertama pada anak dengan SNKM dan obat imunosupresif lain digunakan bila tidak respons dengan pengobatan standar kortikosteroid atau pada relaps frekuen atau dependen steroid. Pemberian kortikosteroid sebaiknya tidak segera dimulai setelah onset gejala karena remisi spontan dapat terjadi pada 5\% kasus SNKM kecuali kalau edema menetap atau gejala berat pada onset awal.
\end{abstract}

Kata kunci: SNKM, kortikosteroid, anak

S indrom nefrotik idiopatik (SNI) adalah suatu sindrom klinik yang ditandai oleh proteinuria masif yang menyebabkan hipoalbuminemia dan biasanya disertai edema dan hiperkolesterolemia dengan penyebab tidak diketahui. Kelainan histologik yang terbanyak pada anak dengan SNI adalah kelainan minimal sehingga disebut sindrom nefrotik kelainan minimal (SNKM). Prevalensi SNKM di negara Barat sekitar 2-3 kasus per 100.000 anak < 16 tahun, ${ }^{1,2,3,4} \mathrm{di}$ Asia 16 kasus per 100.000 anak, ${ }^{1}$ dan di Indonesia sekitar 6 kasus per 100.000 anak < 14 tahun. ${ }^{5}$ Sindrom Nefrotik Kelainan Minimal berdampak pada kesehatan fisik anak serta mental anak dan orang tua karena sering relaps, pengobatan lama, dan toksisitas obat yang serius. Pengobatan yang tidak adekuat potensial

Alamat korespondensi:

Husein Abar, SpA(K).

SMF IKA FK-UNHAS/RSUP Dr Wahidin Sudirohusodo Jl.

Perintis Kemerdekaan Km. 11, Tamalanrea Makasar - Sulsel membahayakan hidup anak karena infeksi sekunder dan dapat menyebabkan tromboemboli, kelainan lipid, dan malnutrisi. Tujuan tata laksana SNKM pada anak yaitu melakukan induksi dan mempertahankan remisi total tanpa toksisitas obat yang serius. ${ }^{3}$ Tulisan ini menguraikan beberapa pilihan tata laksana SNKM pada anak

\section{Batasan $^{2.6,7,8}$}

- Proteinuria masif adalah ekskresi protein urin $>$ $40 \mathrm{mg} / \mathrm{m}^{2} / \mathrm{jam}$ atau $>50 \mathrm{mg} / \mathrm{kgBB} / \mathrm{hari}$.

- Hipoalbuminemia adalah kadar albumin serum < $2,5 \mathrm{mg} / \mathrm{dl}$

- Hiperkolesterolemia adalah kadar kolesterol serum $>250 \mathrm{mg} / \mathrm{dl}$

- Remisi adalah uji dipstix negatif atau trace atau ekskresi protein urin $<4 \mathrm{mg} / \mathrm{m}^{2} / \mathrm{jam}$ atau $<50 \mathrm{mg} /$ $\mathrm{kg}$ berat badan/hari selama 3 hari berturut-turut

- Relaps adalah uji dipstix atau sulfosalicular acid $(\mathrm{SSA})>2^{+}$atau ekskresi protein urin $>40 \mathrm{mg} /$ 
$\mathrm{m}^{2} /$ jam atau $>50 \mathrm{mg} / \mathrm{kg}$ berat badan / hari selama 3 hari berturut-turut.

- Relaps frekuen adalah $=2$ relaps dalam waktu 6 bulan atau $=4$ relaps dalam waktu 12 bulan sesudah respons awal sesudah pengobatan standar prednison

- Dependen steroid adalah relaps = 2 kali berturutturut selama dosis prednison diturunkan atau 14 hari sesudah prednison dihentikan.

- Resistensi steroid adalah kegagalan mencapai remisi walaupun sudah diberikan pengobatan standar prednison dosis penuh selama 8 minggu yaitu setiap hari selama 4 minggu dan selang sehari selama 4 minggu.

\section{Manifestasi klinis}

Edema merupakan gejala klinis utama pada 95\% anak dengan SNKM. ${ }^{4}$ Edema timbul perlahan-lahan pada fase awal, biasanya mulai tampak di daerah resistensi jaringan rendah seperti palpebra, skrotum, atau labia dan berkembang menjadi edema umum dan masif yang disebut anasarca. Edema bersifat piting dan bergantung posisi tubuh sehingga tampak jelas di muka saat bangun pagi dan di tungkai pada siang hari.

Anak dengan SNKM biasanya berumur $>1$ tahun sampai kurang dari 10 tahun $^{2,4,9}$, sekitar 90\% kasus berumur kurang dari 7 tahun $^{7}$ dengan usia rerata $2-5$ tahun, terutama anak lelaki. ${ }^{8}$ Gejala yang menyertai adalah anorexia, pucat, iritabel, lemah, perut terasa penuh, dan diare dapat merupakan keluhan pada anak besar. Bila asites hebat anak mungkin sulit bernapas dan tampak takipnu. Tidak jarang dijumpai demam atau gejala infeksi saluran kemih (ISK) bahkan sepsis karena peritonitis. Riwayat ISPA sering mendahului gejala awal SNKM dan riwayat atopi dilaporkan pada 40-50\% anak yang didahului oleh reaksi hipersensitifitas akibat gigitan serangga, keracunan, alergi makanan, dan pasca imunisasi

\section{Pemeriksaan laboratorium ${ }^{2,4,7,6,10}$}

Proteinuria, merupakan tanda utama pertama SNKM, bersifat selektif dengan rasio albumin/globulin urin tinggi. Menurut ISKDC, jumlah proteinuria yang konsisten dengan diagnosis SNKM yaitu $>40 \mathrm{mg} / \mathrm{m}^{2}$ / jam atau $>50 \mathrm{mg} / \mathrm{kg}$ berat badan /hari atau uji dipstix - SSA $>2^{+}$. Bila ada mikrohematuria tidak menyingkirkan SNKM karena dapat dijumpai pada 20$30 \%$ anak dengan SNKM pada onset awal penyakit tapi kemudian menghilang. Hipoalbuminemia, dengan kadar albumin serum $<2.5 \mathrm{~g} / \mathrm{dL}$, merupakan tanda utama kedua SNKM. Kadar Hb dan hematokrit meningkat bila sudah terjadi hipoalbuminemia berat. Hiperkolesterolemia dengan kadar $>250 \mathrm{mg} / \mathrm{dl}$ biasanya ditemukan dan dapat menetap 1-3 bulan sesudah remisi. Kadar kolesterol LDL dan VLDL meningkat sedangkan HDL menurun atau normal. Fungsi ginjal umumnya normal walaupun kadar kreatinin serum sedikit meningkat pada $25-30 \%$ kasus SNKM pada onset awal penyakit tapi normal kembali pada saat diuresis. Komplemen C3 serum umumnya normal.

\section{Pencitraan}

Pencitraan rutin tidak dianjurkan pada anak dengan SNKM. Foto toraks biasanya menunjukkan efusi pleura yang berkorelasi langsung dengan derajat edema dan tidak langsung dengan kadar albumin serum. Pemeriksaan USG biasanya menunjukkan kedua ginjal normal atau sedikit membesar dengan ekogenitas normal.

\section{Biopsi Ginjal|2,411,12}

Biopsi ginjal tidak dilakukan pada anak dengan SNKM karena 93.1-97\% kasus sensitif terhadap steroid. Indikasi biopsi ginjal yaitu SNKM resisten steroid, umur anak $<1$ tahun atau $>10$ tahun pada saat onset penyakit atau SNI dengan gejala klinis hematuria, hipertensi, dan azotemia persisten dan hipokomplemenemia.

\section{Diagnosis}

Diagnosis SNKM dapat ditegakkan bila memenuhi kriteria berikut,

- Anak umur 2-7 tahun dengan gejala klinis edema

- Proteinuria masif yaitu uji dipstix / SSA $>2+$ atau $>40 \mathrm{mg} / \mathrm{m} 2 / \mathrm{jam} />50 \mathrm{mg} / \mathrm{kg} \mathrm{BB} / \mathrm{hari}$.

- Hipoalbuminemia dengan kadar albumin serum $<2,5 \mathrm{~g} / \mathrm{dl}$ 
- Dapat disertai hiperkolesterolemia dengan kadar $>250 \mathrm{mg} / \mathrm{dl}$

- Tidak ada hematuria

- Tekanan darah normal

- Kreatinin serum normal

- Komplemen C3 serum normal

\section{Tata laksana}

\section{Tata laksana suportif}

1. Aktifitas bergantung keadaan umum anak, ${ }^{4}$ sedangkan tirah baring tidak dianjurkan kecuali karena tirah baring potensial meningkatkan risiko trombosis terdapat edema anasarka dan disertai komplikasi. $^{7}$

2. Asupan garam dibatasi untuk pencegahan dan pengobatan edema ${ }^{2,7}$ selain mengurangi resiko hipertensi selama pengobatan prednison. ${ }^{2}$ Diit rendah garam hanya pada kasus edema berat ${ }^{7}$ sedangkan kalori harus adekuat, karbohidrat normal, dan relatif rendah lemak. ${ }^{2,4}$ Asupan protein diusahakan mencapai target $130-140 \%$ kebutuhan nomal harian sesuai usia atau $1-2 \mathrm{~g} / \mathrm{kg}$ berat badan/hari. Pembatasan cairan dianjurkan pada keadaan hiponatremia sedang - berat. ${ }^{7}$

3. Diuretik.

Pemberian diuretik umumnya tidak diperlukan pada SNKM karena dapat memicu renjatan hipovolemik; namun pada kasus dengan edema berat disertai kesulitan napas ${ }^{2,7}$ boleh diberikan furosemid oral 1-2 mg/kg/hari sesudah koreksi hipovolemia atau spironolakton $2-10 \mathrm{mg} / \mathrm{kg} \mathrm{BB} /$ hari bila kreatinin serum normal. ${ }^{7}$

4. Albumin

Albumin meningkatkan tekanan onkotik dan membantu efek diuretik furosemid. Hipovolemia, yang timbul dengan cepat akibat hilangnya protein plasma dan dipicu oleh pemberian diuretik, ${ }^{7}$ potensial menyebabkan syok pada anak dengan SNKM. Manifestasi syok meliputi nyeri perut, akral dingin, volume nadi kurang, hipotensi, dan hemokonsentrasi. Untuk mencegah renjatan diberikan infus albumin $0.5-1 \mathrm{~g} / \mathrm{kg} /$ dosis per infus $(5 \mathrm{mg} / \mathrm{kg}$ berat badan albumin $20 \%$ atau $25 \%)$ selama $1-4$ jam bersama dengan pemberian furosemid. ${ }^{2,4,7,8}$ Status hidrasi anak harus monitoring karena pernah dilaporkan adanya edema paru dan gagal jantung kongestif. ${ }^{7}$ Akibat pemberian albumin tidak rutin diberikan pada semua anak dengan SNKM atau SNKM relaps. ${ }^{8}$

5. Obat penyekat ACE seperti kaptopril sebagai pengobatan tambahan dapat mengurangi ekskresi protein urin sebanyak 50\%. Namun kegunaan jangka panjang pada anak belum terbukti mencegah progresifitas penyakit. Obat ini jangan diberikan selama pemberian dosis awal prednison karena dapat menimbulkan hipotensi dan resiko trombosis. $2,4,13$

6. Hiperkolesterolemia umumnya bersifat transien dan normal kembali bila pengobatan berhasil. Masih belum ada rekomendasi berbasis bukti untuk pengobatan hiperkolesterolemia., ${ }^{27,8}$

\section{Tata laksana komplikasi}

1. Pencegahan infeksi. Tidak dianjurkan antibiotik profilaksis ${ }^{4}$ karena tidak efektif dalam mencegah peritonitis. ${ }^{2}$ Pemberian antibiotik hanya dianjurkan bila ada bukti infeksi. ${ }^{4}$

- Peritonitis primer merupakan komplikasi fatal yang disebabkan oleh Streptococcal pneumoniae (50\%), E. coli, Streptococcus B, Haemophilus influenzae dan basil gram negatiflain ${ }^{27,8,10,}$ Gejala peritonitis berupa nyeri perut, muntah, dan demam disertai leukositosis dan CRP positif. ${ }^{7}$ Pengobatan dengan antibiotik spektrum lebar atau sefalosporin generasi ketiga., 2,

- Selulitis dengan gejala erisipeloid pada kulit perut atau paha akibat edema kulit dan jaringan subkutis serta imunitas yang rendah. Penyebab selulitis adalah $S$. pneumoni, $S$. hemolyticus, stafilokokus atau basil gram negatif. Pencegahan dengan higiene dan perawatan kulit yang baik. ${ }^{10}$

- Cegah kontak dengan pasien varisela atau morbili dan bila telah terjadi kontak maka sebaiknya diberikan imunoglobulin variselazoster 72 jam atau imunoglobulin intravena dosis tunggal sesudah kontak dengan pasien varisela disertai asiklovir untuk varisela dan morbili dan dosis prednison diturunkan $1 \mathrm{mg} /$ $\mathrm{kg}$ BB hari sampai masa inkubasi varisela atau morbili berakhir.

- Dianjurkan uji tuberkulin bila pasien kontak dengan TB dewasa. ${ }^{4}$ 
2. Imunisasi

Anak dalam pengobatan prednison atau imunosupresif lain hanya mendapat vaksin virus mati sedangkan vaksin virus hidup baru boleh diberikan 6 bulan sesudah prednison dihentikan. ${ }^{2}$

3. Gagal ginjal akut (GGA)

Jarang terjadi GGA pada anak dengan SNKM sensitif steroid. Penyebab pasti belum diketahui walaupun hipovolemia mungkin sebagai salah faktor pencetus selain faktor intrarenal lain. Pengobatan dengan koreksi deplesi volume darah dengan infus albumin diikuti oleh furosemid 1-2 $\mathrm{mg} / \mathrm{kg}$ BB intravena. ${ }^{7,8,10}$

4. Trombosis

Bila curiga trombosis lakukan pemeriksaan lengkap dan segera obati untuk mencegah komplikasi fatal karena trombosis vena, atau agak jarang trombosis arteri, potensial menyebabkan emboli paru. Pengobatan terdiri dari obat antikoagulan dan pada kasus dengan gejala tromboembolik dianjurkan obat antitrombotik dan antikoagulan. Hati-hati pemakaian diuretik pada kasus SNKM karena hipovolemia merupakan salah satu faktor predisposisi trombosis dan sebaiknya dihindari pada kasus dengan gejala tromboembolik.

Pengobatan harus diberikan sesudah konsultasi dengan konsultan nefrologi anak. ${ }^{2,7,8,10}$

5. Krisis adrenal akut

Keadaan ini dapat dijumpai pada anak dengan pengobatan kortikosteroid lama dengan dosis 18 $\mathrm{mg} / \mathrm{m}^{2}$ kortison per hari.

\section{Tata laksana spesifik}

\section{Pemberian kortikosteroid pada SNKM}

Pemberian kortikoseroid baik prednison maupun prednisolon sebaiknya tidak segera dimulai setelah onset gejala karena remisi spontan dapat terjadi pada 5\% kasus SNKM; kecuali kalau edema menetap atau gejala berat pada onset awal. ${ }^{7}$ Semua glukokortikoid efektif, namun prednison oral yang paling banyak digunakan ${ }^{4}$ dan umumnya lebih disukai dari prednisolon. ${ }^{10}$ Cara kerja spesifik tidak diketahui walaupun prednison menekan sistem imun. ${ }^{4}$ Sampai saat ini, prednison tetap merupakan pilihan pertama pada anak dengan SNKM dan obat imunosupresif lain digunakan bila tidak respons dengan pengobatan standar prednison atau pada relaps frekuen atau dependen steroid. $^{2,4}$

\section{Efek samping kortikosteroid}

Efek samping prednison bergantung besar dosis, frekuensi pemberian, dan lama pengobatan. Efek samping prednison ringan-sedang meliputi perobahan sikap dan tingkah laku seperti emosi labil, nafsu makan bertambah, moon face, obesitas, dan hirsutisme umumnya muncul 6 minggu pertama setelah pengobatan prednison harian tapi berkurang selama pengobatan rumatan atau selama penghentian prednison bertahap dan umumnya menghilang dalam waktu 3-6 bulan. Bila prednison dosis tinggi diberikan jangka lama maka risiko toksisitas bertambah berat meliputi perubahan tingkah laku hebat sampai psikosis steroid, hipertrofi ginggiva, habitus cushingoid, iritasi lambung sampai ulkus, hiperlipidemia, hiperglikemia, hiperkalsiuria, hipokalemia, obesitas, retardasi pertumbuhan, osteopenia, osteoporosis, nefrolitiasis, osteomalasia, hipertensi, fungsi imun menurun, pseudotumor serebri, atrofi otak, alkalosis metabolik, miopati, dan DM steroid. $2,4,10$

Prednison tidak dianjurkan bila ada bukti hipersensitivitas, infeksi bakteri, virus, atau jamur aktif. Bila pengobatan antibakteri, antivirus, atau anti jamur telah memberikan respons baik maka prednison boleh diberikan. Prednison mengurangi efek salisilat dan vaksinasi toksoid sedangkan fenitoin, karbamazepin, luminal, dan rifampin mengurangi efek prednison. ${ }^{4}$

\section{Pengobatan SNKM serangan pertama}

a. Pengobatan SNKM menurut ISKDC 4-4 atau modifikasi 6-6 sebagai berikut, Pengobatan induksi dengan prednison oral $2 \mathrm{mg} / \mathrm{kg}$ berat badan/hari atau $60 \mathrm{mg} / \mathrm{m}^{2}$ luas permukaan badan /hari (maksimum $80 \mathrm{mg} /$ hari) setiap hari dalam 1-3 dosis terbagi selama 4-6 minggu; dilanjutkan dengan.

Pengobatan rumatan dengan prednison oral $1,5 \mathrm{mg} / \mathrm{kg}$ berat badan /hari atau $40 \mathrm{mg} / \mathrm{m}^{2}$ luas permukaan badan setiap pagi selang sehari ${ }^{9}$ atau dua - tiga dosis ${ }^{4}$ selama 4-6 minggu ${ }^{2,4,8,9}$ dan dapat langsung dihentikan atau dihentikan secara bertahap. 
Pengobatan SNKM menurut Konsensus UKK Nefrologi IDAI Pengobatan sesuai anjuran ISKDC dengan prednison oral $60 \mathrm{mg} / \mathrm{m}^{2}$ luas permukaan badan / hari atau $2 \mathrm{mgk} / \mathrm{kg}$ berat badan ideal (berat badan terhadap tinggi badan) /hari (maksimal 80mg/hari) dibagi 3 dosis selama 4 minggu untuk induksi remisi. Bila terjadi remisi dalam minggu pertama maka prednison oral dilanjutkan selama 4 minggu kedua dengan dosis 40 $\mathrm{mg} / \mathrm{m} 2$ luas permukaan badan /hari setiap pagi selang sehari diberikan sesudah makan. Namun bila tidak terjadi remisi selama 4 minggu pertama maka diagnosis dan pengobatan sebagai sindrom nefrotik resisten steroid. ${ }^{14}$

Angka relaps dilaporkan lebih tinggi (61\%) pada regimen 4-4 minggu daripada regimen 6-6 minggu $(36 \%) .{ }^{10}$ Dosis harian lebih tinggi atau waktu lebih lama tidak mengubah secara bermakna angka respons pada SNKM malahan toksisitas lebih meningkat. Sekitar 90\% anak dengan SNKM berikan respons umumnya pada hari ke $10-14$. Bila tidak berikan respons dirujuk ke konsultan nefrologi anak. ${ }^{4}$

Ueda dkk ${ }^{15}$ dan Ksiazek-Wysznska ${ }^{16}$ melaporkan angka bebas relaps 2 tahun pada 50\% kasus dengan pengobatan prednison jangka panjang dan $27.3 \%$ jangka pendek. Pengobatan prednison jangka panjang yaitu prednison 60 $\mathrm{mg} / \mathrm{m} 2 /$ hari (maksimum $80 \mathrm{~g} /$ hari) selama 4 minggu; dilanjutkan dengan $40 \mathrm{mg} / \mathrm{m} 2 / 48$ jam selama 4 minggu; dan kemudian dosis dikurangi 25\% setiap bulan selama 4 bulan $^{2,4,9}$ sedangkan jangka pendek menurut ISKDC $2,9,10,11$ yaitu prednison $60 \mathrm{mg} / \mathrm{m} 2 /$ hari (maksimum $80 \mathrm{mg} / \mathrm{hari}$ ) selama 4 minggu dan dilanjutkan dengan $40 \mathrm{mg} / \mathrm{m} 2 / 48$ jam selama 4 minggu. Laporan dari Cochrane Database menyimpulkan bahwa risiko relaps selama 12-24 bulan lebih rendah secara bermakna dan tanpa peningkatan toksisitas pada pengobatan prednison selama 3 bulan atau lebih dari pada pengobatan prednison hanya 4-6 minggu. Simpulan meta-analisis terakhir yaitu angka relaps berkurang sebanyak 33\% bila diberikan prednison setiap hari selama 4-6 minggu dan dilanjutkan dengan dosis rumatan selang sehari selama 6 bulan. ${ }^{4}$

b. Pengobatan SNKM jangka panjang 4-8-8-8. ${ }^{4}$

- Pengobatan induksi dengan prednison oral 2 $\mathrm{mg} / \mathrm{kg}$ /hari setiap hari selama 4 minggu, dilanjutkan dengan

- Pengobatan rumatan dengan prednison oral $1,5 \mathrm{mg} / \mathrm{kg}$ setiap pagi selang sehari selama 8 minggu; dilanjutkan dengan

- Prednison oral $1.0 \mathrm{mg} / \mathrm{kg}$ setiap pagi selang sehari selama 8 minggu; dilanjutkan dengan
- Prednison oral $0.5 \mathrm{mg} / \mathrm{kg}$ setiap pagi selang sehari selama 8 minggu

- Hentikan prednison.

\section{Pengobatan SNKM relaps}

Sekitar 92\% anak dengan SNKM memberikan respons terhadap pengobatan standar prednison. Duapuluh sampai limapuluh persen (rerata 30\%) memberikan respons pada awal pengobatan, $20-50 \%$ mengalami relaps tidak frekuen, dan $25-50 \%$ (rerata 35\%) mengalami relaps frekuen. ${ }^{4}$ Bila proteinuria muncul kembali sesudah infeksi dan tidak ada gejala edema maka berikan antibiotik seperti amoksisilin atau sefaleksin selama 6-7 hari dan tidak perlu berikan prednison. Prednison diberikan bila proteinuria tetap $>3^{+} 1$ minggu sesudah infeksi sembuh. Relaps awal umumnya terjadi $=3$ bulan sesudah remisi, yang biasanya disebabkan oleh infeksi atau alergi saluran napas, dan cenderung segera memberikan respons terhadap prednison. ${ }^{17,18}$ meliputi;

- Pengobatan SNKM relaps. ${ }^{2,9}$

- Pengobatan reinduksi dengan prednison oral $2 \mathrm{mg} /$ $\mathrm{kg} \mathrm{BB} /$ hari $60 \mathrm{mg} / \mathrm{m}^{2} /$ hari (maksimum $80 \mathrm{mg}$ / hari) sampai tercapai remisi; dilanjutkan dengan

- Pengobatan rumatan dengan prednison oral 1,5 $\mathrm{mg} / \mathrm{kg}$ atau $40 \mathrm{mg} / \mathrm{m}^{2}$ setiap pagi selang sehari selama 4-6 minggu; dan kemudian

- Dosis diturunkan secara bertahap selama 4 minggu.

\section{Pengobatan SNKM relaps frekuen}

Anak dengan SNKM relaps frekuen mempunyai dampak yang serius terhadap progresifitas penyakit dan toksisitas prednison. Relaps frekuen pada kasus dengan gejala klinis toksisitas prednison sebaiknya dirujuk ke konsultan nefrologi anak untuk pemberian obat sitotoksik seperti siklosfosfamid atau klorambusil. Penelitian terkontrol siklofosfamid pada kasus relaps frekuen menunjukkan bahwa $>50 \%$ kasus mengalami remisi selama 2-3 tahun dan sekitar $20 \%$ gagal mencapai remisi. Bila obat sitotoksik tidak berhasil mempertahankan remisi atau terjadi relaps frekuen, boleh dicoba dengan bolus metilprednison intermiten. Anak dan orang tua harus diberitahu tentang toksisitas obat sitotoksik seperti sterilitas atau teratogenesis. ${ }^{4,9}$ 
Pada anak dengan SNKM relaps frekuen dapat digunakan beberapa pilihan pengobatan, yaitu:

a Pilihan pertama ${ }^{11}$

Pengobatan reinduksi dengan prednison oral $2 \mathrm{mg} /$ $\mathrm{kgBB}$ atau $60 \mathrm{mg} / \mathrm{m}^{2} /$ hari (maksimum $80 \mathrm{mg} /$ hari) sampai remisi; dilanjutkan dengan pengobatan rumatan dengan prednison oral $1,5 \mathrm{mg} / \mathrm{kg}$ atau $40 \mathrm{mg} / \mathrm{m}^{2}$ setiap pagi selang sehari selama 4 minggu dan hentikan bertahap.

b. Pilihan kedua. ${ }^{9}$

Pengobatan dengan prednison oral $60 \mathrm{mg} / \mathrm{m}^{2} /$ hari atau $1,5 \mathrm{mg} / \mathrm{kg}$ berat badan /hari sampai remisi dan selanjutnya dosis dikurangi secara bertahap sampai dosis rendah $0,1-0.5 \mathrm{mg} / \mathrm{kg}$ setiap pagi selang sehari selama 3 - 6 bulan. Bila timbul relaps dengan dosis prednison rendah selang sehari maka anak direinduksi sebagai relaps dan prednison diturunkan lagi bertahap sampai dosis rendah selang sehari.

c. Pilihan ketiga. ${ }^{10}$

Pengobatan dengan prednison oral $40-60 \mathrm{mg} / \mathrm{m}^{2 /}$ hari sampai 4-5 hari bebas proteinuria; dilanjutkan dengan prednison oral setiap pagi selang sehari dan dosis diturunkan bertahap sampai $15-20 \mathrm{mg} / \mathrm{m}^{2}$ selama 12-18 bulan.

d. Pilihan keempat. ${ }^{9}$

Siklofosfamid 2-2,5 mg/kg/hari atau klorambusil 0,15 $-0,20 \mathrm{mg} / \mathrm{kg} / \mathrm{h}$ ari selama 8 minggu dapat dipertimbangkan pada kasus relaps frekuen dan kasus dengan gejala klinis toksisitas prednison atau levamisol $2,5 \mathrm{mg} /$ $\mathrm{kg} /$ hari selang sehari selama $6-12$ bulan pernah dicoba pada anak dengan SNKM relaps frekuen., ${ }^{2,10,19}$ Efek samping dini jarang meliputi neutropenia, ruam, gangguan saluran cerna, dan kejang. ${ }^{2}$

\section{Pengobatan SNKM dependen steroid}

Pada anak dengan SNKM dependen steroid dapat digunakan beberapa pilihan pengobatan:

a Pilihan pertama ${ }^{11}$

Pengobatan reinduksi seperti pada kasus SN relaps dengan prednison oral $2 \mathrm{mg} / \mathrm{kg}$ berat badan /hari atau $60 \mathrm{mg} / \mathrm{m}^{2} /$ hari sampai remisi; dilanjutkan dengan prednison oral $1,5 \mathrm{mg} / \mathrm{kg}$ berat badan atau $40 \mathrm{mg} / \mathrm{m}^{2} /$ selang sehari selama 4 minggu. Hentikan bertahap

b. Pilihan kedua ${ }^{9}$

Reinduksi dengan prednison oral $2 \mathrm{mg} / \mathrm{kg}$ berat badan /hari atau $60 \mathrm{mg} / \mathrm{m}^{2} /$ hari sampai remisi; dilanjutkan dengan prednison oral $1,5 \mathrm{mg} / \mathrm{kg}$ berat badan /selang sehari dengan dosis diturunkan secara bertahap sampai dosis rendah $0,1-0,5$ $\mathrm{mg} / \mathrm{kg} / \mathrm{selang}$ sehari selama $6-12$ bulan.

c. Pilihan ketiga ${ }^{9}$

Pengobatan dengan prednison oral 40-60 $\mathrm{m}^{2} /$ hari sampai 4-5 hari bebas proteinuria; dilanjutkan dengan prednison oral selang sehari dosis diturunkan secara bertahap sampai $15-20 \mathrm{mg} / \mathrm{m}^{2}$ selama $12-18$ bulan. $^{10}$

d. Pilihan keempat. ${ }^{4,8,9}$

Pengobatan dengan siklofosfamid oral $2-2,5 \mathrm{mg} /$ $\mathrm{kg} / \mathrm{hari}$ atau siklofosfamid puls intravena selama 6 bulan atau klorambusil $0,15-0.20 \mathrm{mg} / \mathrm{kg} / \mathrm{h}$ ari selama 8-12 minggu atau siklosporin A 3-6 mg/ $\mathrm{kg} /$ hari selama 1 tahun.

Anak dianjurkan minum banyak dan sering berkemih untuk mengurangi iritasi kandung kemih. Toksisitas akut siklofosfamid meliputi nausea, muntah, leukopenia, alopesia, infeksi, gangguan saluran cerna.dan sistitis hemorhagik sedangkan toksisitas jangka panjang meliputi kerusakan kromosom, neoplasia, azospermia, fibrosis ovarium dan infertilitas terutama lelaki bila dosis kumulatif $>170 \mathrm{mg} / \mathrm{kg}^{2,8,10,13}$ Berbagai penelitian termasuk ISKDC menunjukan keunggulan kombinasi siklofosfamid dan prednison dibandingkan dengan prednison tunggal dalam mempertahankan lama remisi. ${ }^{4,18,20}$ Sementara anak dalam pengobatan siklofosfamid, dosis prednion dapat diturunkan secara bertahap dan dihentikan bila pemberian siklofosfamid sudah lengkap dan anak masih tetap remisi. laporan APN menunjukkan bahwa angka remisi 2 tahun lebih tinggi pada SNKM dependen steroid (67\%) bila pemberian siklosfamid 2 $\mathrm{mg} / \mathrm{kg} /$ hari selama 12 minggu dibandingkan dengan (22\%) 8 minggu, ${ }^{2}$ namun Ueda dkk tidak menemukan perbedaan bermakna siklofosfamid 8 minggu dan 12 minggu. ${ }^{21}$ Periksa darah rutin dan urinalisis setiap 2 minggu bila sedang dalam pengobatan siklofosfamid oral.

\section{Pengobatan SNKM resisten steroid}

Pengobatan pada anak dengan sNKM yang terbukti resisten prednison sebagai berikut,

a. Metilprednisolon $10-30 \mathrm{mg} / \mathrm{kg}$ BB diberikan dalam 
bentuk bolus intravena selang sehari dengan total pemberian 6-9-12 suntikan, diikuti oleh prednison oral setiap pagi selang sehari. ${ }^{2,13}$ Pengobatan in sebaiknya dilakukan oleh konsultan nefrologi anak. ${ }^{2}$

b. Siklofosfamid $2-2,5 \mathrm{mg} / \mathrm{kg} /$ hari selama $8-12$ minggu $^{9,13}$ lebih disukai dosis pagi hari, diberikan bersama prednison oral $0,5 \mathrm{mg} / \mathrm{kg} \mathrm{BB}$ setiap pagi selang sehari untuk mengurangi toksisitas siklofosfamid. ${ }^{13}$ atau dengan siklofosfamid puls intravena selama 6 bulan. ${ }^{9}$ Klorambusil 0,15 - 0,20 mg/kg (dosis kumulatif $<10 \mathrm{mg} / \mathrm{kg}$ ) selama 8 minggu.

Toksisitas klorambusil lebih sering daripada siklofosfamid berupa supresi sumsum tulang, infeksi, kejang fokal dan risiko tinggi terjadi neoplasma seperti leukemia atau limfoma maligna serta sterilitas terutama anak lelaki pada pemakaian jangka panjang dengan kumulatif $>10 \mathrm{mg} /$ $\mathrm{kgBB} \cdot{ }^{8,10,13}$ Sistitis hemorhagik umumnya disebabkan oleh siklosfosfamid tapi tidak oleh klorambusil, sedangkan kejang disebabkan oleh klorambusil tapi tidak oleh siklofosfamid. ${ }^{2}$

c. Siklosporin A 3-6 mg/kg/hari selama 1-2 tahun. ${ }^{8,9,13}$ Siklosporin A ternyata dapat mempertahankan remisi pada $80 \%$ anak dengan SNKM. ${ }^{22}$

Efek samping siklosporin A meliputi hipertensi, nefropati toksis, kreatinin serum meningkat, hiperkalemia, hipomagnesemia, hipertrikosis, dan hiperplasia ginggiva. ${ }^{2,10}$

\section{Relaps pasca obat sitotoksik}

Relaps yang terjadi sesudah pengobatan standar siklofosfamid dapat diobati kembali sebagai kasus relaps bila tidak ada gejala toksisitas prednison. Namun, bila relaps segera timbul sesudah henti prednison dan atau disertai gejala toksisitas prednison maka sebaiknya dirujuk ke konsultan nefrologi anak. Kasus SNKM yang termasuk kelompok ini hanya sekitar $10-20 \%$. Secara singkat, alur tatalaksana spesifik SNKM dapat dilihat pada Gambar 1.

\section{Rawat inap dan rawat jalan}

Sesudah diagnosis SNKM ditegakkan segera edukasi anak dan orang tua tentang penyakit, tata laksana, dan perjalanan penyakit, serta aspek psikososial. Orang tua sebaiknya berperan aktif di dalam keputusan pengobatan dan tata cara pengobatan. Tidak semua kasus SNKM harus dirawat di RS. Indikasi medis bila terdapat edema masif disertai kesulitan napas, anuria atau oliguria hebat, peritonitis, Infeksi saluran napas signifikan, azotemia signifikan, atau karena alasan sosial. ${ }^{4}$ Lama rawat inap biasanya singkat yang dilanjutkan dengan rawat jalan secara teratur.

Pemantauan keadaan umum anak dan respons pengobatan selama rawat jalan merupakan aspek penting dari seluruh tata laksana SNKM. Prognosis menjadi lebih baik bila orang tua selalu memperhatikan keadaan anak dan kemajuan pengobatan. Hal ini harus dilakukan secara rutin dan dimulai pada awal rawat jalan. Pemantauan dilakukan terhadap keadaan umum, gejala dan derajat edema, tekanan darah, penyakit penyerta, produksi urin per 24 jam, hasil pemeriksaan protein urin dan darah, serta hasil pengobatan. Pelacakan albuminuria dapat dilakukan secara teratur di rumah menggunakan cara dipstix dan di puskesmas atau RS dengan uji SSA dan cara kuantitatif dan hasil uji dicatat di dalam buku kesehatan anak sehingga segera mengetahui relaps sebelum timbul gejala edema dan pengobatan awal dapat segera dimulai.

Anak dengan SNKM resisten awal prednison, relaps awal selama dalam pengobatan rumatan, relaps frekuen, dependen dan resisten steroid sebaiknya dikonsultasikan dengan konsultan nefrologi anak. ${ }^{4}$

\section{Pencegahan}

Mengatasi timbulnya relaps sangat penting. Relaps kebanyakan terjadi sesudah infeksi saluran napas sehingga upaya mencegah anak kontak dengan pasien infeksi saluran napas sangat bermanfaat. Relaps dapat juga timbul sesudah imunisasi oleh karena itu lebih disukai menunda imunisasi rutin sampai anak dalam keadaan remisi dan sekitar 6 bulan bebas prednison. ${ }^{4}$

\section{Kesimpulan}

Sindrom Nefrotik Kelainan Minimal berdampak pada kesehatan fisik anak serta mental anak dan orang tua karena sering relaps, pengobatan yang lama, dan toksisitas obat yang serius. Pengobatan yang tidak adekuat potensial membahayakan hidup anak karena 
Sari Pediatri, Vol. 8, No. 1, Juni 2006

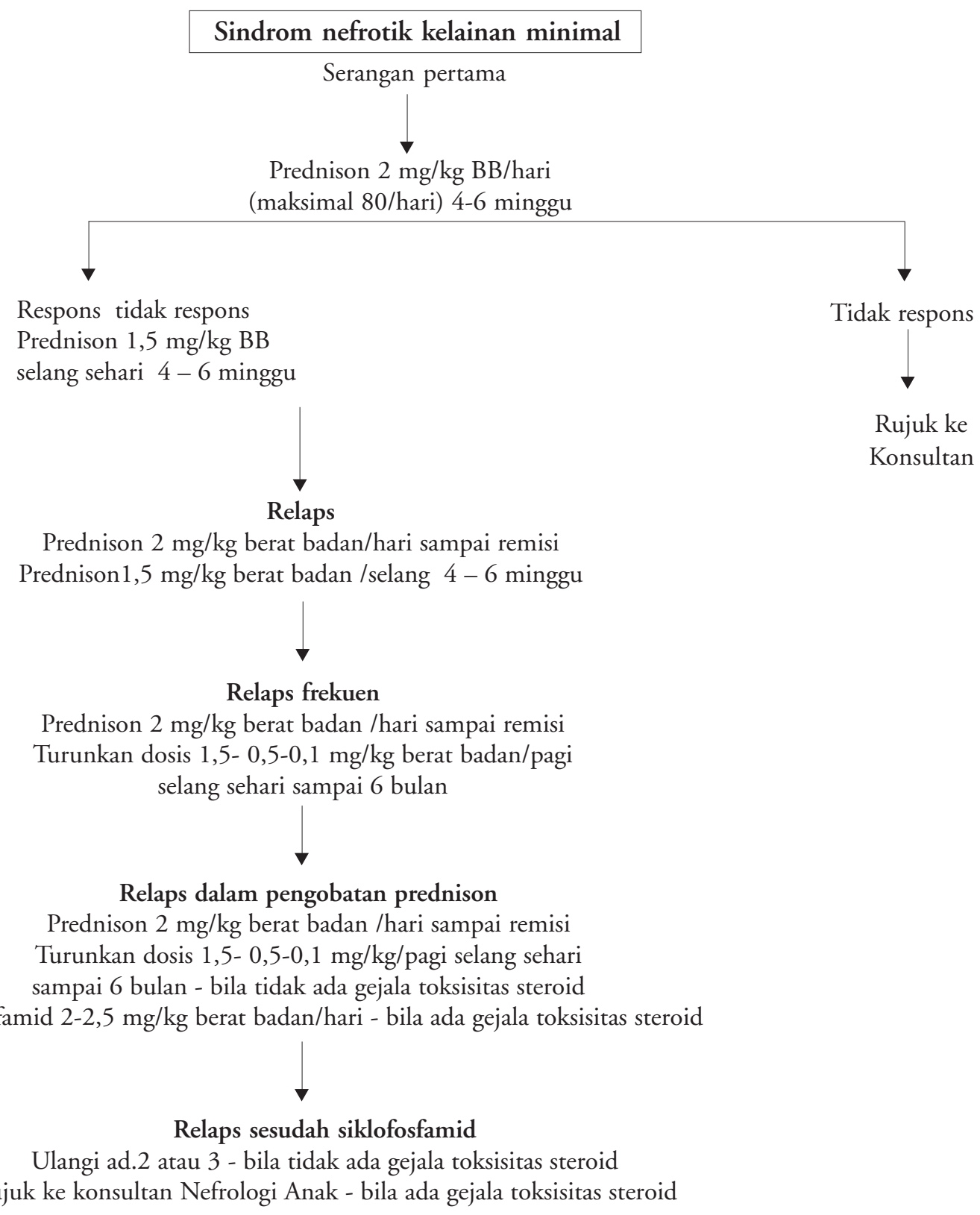

Gambar 1. Alur tata laksana spesifik Sindrom nefrotik kelainan minimal

infeksi sekunder dan dapat menyebabkan tromboemboli, kelainan lipid, dan malnutrisi. Tujuan tata laksana SNKM pada anak yaitu melakukan induksi dan mempertahankan total tanpa toksisitas obat yang serius. Pada umumnya anak dengan SNKM sensitif terhadap prednison sehingga prednison merupakan pilihan utama untuk induksi remisi. Orang tua sebaiknya ikut serta dalam keputusan pengobatan; oleh karena itu perlu edukasi anak dan orang tua tentang perjalanan penyakit, tata laksana, dan aspek psikososial. Pemantauan selalu dilakukan terhadap keadaan umum anak, kemajuan pengobatan, dan gejala toksisitas obat.

\section{Daftar Pustaka}

1. Sharples PM, Poulton J, White RHR. Steroid responsive nephrotic syndrome is more common in Asians. Arch Dis Child 1985; 60:1014-7. 
2. Hogg JR et al. Evaluation and management of proteinuria and nephritic syndrome in children. Recommendation from a Pediatric Nephrology panel established at the national kidney foundation conference on proteinuria, albuminuria, risk, assessment, detection, and elimination (PARADE). Pediatrics 2000; 105: 8-14.

3. Hodson E. The management of idiopathic nephrotic syndrome in children. Paediatr Drugs. 2003;5:335-49.

4. T Luther. nephrotic syndrome, Didapat dari: http:/// www.emedicine com / ped / topic $1564 \mathrm{htm}$. Last updated: April 14, 2005

5. Wila Wirya IGN. Penelitian beberapa aspek klinis dan patologi anatomis sindrom nefrotik primer pada anak di Jakarta. Disertasi Fakultas Kedokteran Universitas Indonesia 1992.

6. Report of APN. Cyclophosphamide treatment of steroid dependent nephroti syndrome : comparison of 18 weeks with twelve weeks. Arch Dis Child 1987; 62:1102-06.

7. Niaudet P, Kenda R. Management of steroid reponsive idiopathic nephrotic syndrome. European Society for Paediatric Nephology (ESPN). Handbook edisi kedua. Cochat P. 2002. h. 255-7.

8. Haycock G. The child with idiopathic nephrotic syndrome. Dalam: Clinical paediatric nephrology edisi ketiga. Penyunting. Webb N \& Postlethwaite R. Oxford Medical Publications. 2003. h. 346-61.

9. National Guideline Clearinghouse. 2003-2005 Glomerulonephritis. Guideline status. current release of the guideline. Management of membranous nephropathy; management of childhood nephrotic syndrome. Didapat dari: www. Guidelines.gov/summary.asp?doc.id 2005.

10. Edefonti A, Lilolva M. Complications of the nephrotic syndrome. European Society for Paediatric Nephology (ESPN) Handbook ed. Cochat P. 2002. h. 251-3.

11. A Report of the ISKDC. The primary nephrotic syndrome in children. Indentification of patients with minimal change nephrotic syndrome from initial response to prednisone. J. Pediatr 1981; 98:561-4.

12. White RHR, Glasgow EF, Mills RJ. Clinicopathological study of nephrotic syndrome childhood. Lancet 1970 I:1353-9.

13. Fydryk J, Querfeld U. Idiopathic steroid resistant nephrotic syndrome. European Society for Paediatric Nephology (ESPN). Handbook edisi kedua. Cochat P. 2002. h. 259-61

14. UKK Nefrologi IDAI. Konsensus tatalaksana sindrom nefrotik idiopatik pada anak Penyunting. Alatas $\mathrm{H}$, Tambunan T, Trihon PP, dan Pardede SO, 2005.

15. Ueda N, Chihara M, Kawaguchi S 1 . Intermittent versus long-term tapering prednisone for intial therapy in children with idiopathic nephrotic syndrome. J Pediatr 1988; 112:122-6.

16. Ksiazek J, Wyszynska T. Short versus long initial prednisone treatment in steroid sensitive nephrotic syndrome in children. Acta Paediatr 1995; 84:889-93.

17. Lewis MA, Baidom EM, Davis N, Houston IB, Postlethwaite RJ. Nephrotic syndrome: from toddlers to twenties.Lancet 1989; 1:255-9.

18. Chiu J, McLain PN, Drummond KN. A controlled prospective study of cyclophosphamide in relapsing corticosteroid responsive, minimal lesion nephrotic syndrome in childhood. J Pediatr 1973; 82:607-13.

19. British Association for Paediatric Nephrology. Levamisole for corticosteroid dependent nephrotic syndrome in childhood. Lancet 1991; I:555-8.

20. A Report of the ISKDC. Prospective controlled trial of cyclophosphamide therapy in children with the nephrotic syndrome. Lancet 1974; I; 423-7.

21. Ueda N, Kuno K, Ito S. Eight and 12 week courses of cyclophosphamide in nephrotic syndrome. Arch Dis Child. 1990; 65:1147-50.

22. Niaudet P, Broyer M, Habib R. Treatment of idiopathic ephrotic syndrome with cyclosporin A in children. Clin Nephrol 1991; 35 Suppl 1:S31-6. 